\title{
EFFECT OF BANANA CONSUMPTION AND WALKING EXERCISE ON ANXIETY IN FEMALE ADOLESCENTS
}

\author{
Egy Sunanda Putra'), Brian Wasita'), Sapja Anantanyu3) \\ ${ }^{1)}$ Masters Program in Nutrition, Universitas Sebelas Maret \\ 2)Faculty of Medicine, Universitas Sebelas Maret \\ 3) Faculty of Agriculture, Universitas Sebelas Maret
}

\begin{abstract}
Background: Mental health disorders including anxiety are important global public health issues. The prevalence of anxiety in the Indonesian population aged 15 years and over is 6\%. This study aimed to examine the effect of banana consumption and walking exercise on anxiety in female adolescents.

Subjects and Method: This was a randomized controlled trial conducted in 4 High Schools in Surakarta, Central Java. A sample of 62 female students aged 1517 years with normal nutritional status, fruit consumption $<3 x /$ day, physical exercise <3x/week, no smoking and alcoholic beverages, and not being menstruated during the study, were selected for this study. The sample was divided into 4 groups: (1) banana group; (2) walking exercise group; (3) banana and walking exercise group; (4) control group. The banana group was given 2 bananas per day for 14 days. The walking exercise group walked 3x/ week for 14 days with a distance of $0.8 \mathrm{~km}$ in 15 minutes, a speed of $3.0 \mathrm{~km} / \mathrm{h}$ every $1 \mathrm{x}$ physical exercise, using a treadmill Precor 956i USA. The dependent variable was anxiety. The independent variable was banana, walking exercise, or combination of the two. Anxiety was measured by the Hamilton Anxiety Rating Scale (HARS) questionnaire. Data on other variables were collected by questionnaire. Data were analyzed by the linear regression model.

Results: Banana consumption ( $b=-7.84 ; p<0.001)$, walking exercise $(b=-5.46$; $\mathrm{p}=0.003)$, banana consumption and walking exercise $(b=-11.51 ; p<0.001)$ for 14 days lowered anxiety level in female adolescent.

Conclusion: Either consumption of bananas, walking exercise, or combination of the two, is effective to reduce anxiety in female adolescents.
\end{abstract}

Keywords: banana, walking exercise, anxiety, female, adolescent

\section{Correspondence:}

Egy Sunanda Putra. Masters Program in Nutrition, Universitas Sebelas Maret Surakarta, Jl. Ir.Sutami No. 36 A, 57126, Surakarta, Central Java.

Email: egyputra93@gmail.com. 